Marquette University

e-Publications@Marquette

$4-1-2010$

By Invitation Only: The American Library Association and the Woman's Building Library of the World's Columbian Exposition, Chicago, 1893

Wayne A. Wiegand

Florida State University

Sarah Wadsworth

Marquette University, sarah.wadsworth@marquette.edu

Originally published in Signs: Journal of Women in Culture and Society, Volume 35, No. 3 (Spring 2010), DOI.

This version of the article is identical to the published version.

Published as a chapter in Right Here I See My Own Books: The Woman's Building Library at the World's

Columbian Exposition, Sarah Wadsworth and Wayne Wiegand, eds. University of Massachusetts

Press, 2012. http://www.umass.edu/umpress/title/right-here-i-see-my-own-books 
Wayne $A$. Wiegand

Sarah Wadsworth

\section{By Invitation Only: The American Library Association and the Woman's Building Library of the World's Columbian Exposition, Chicago, 1893}

B

y invitation only, at 9:30 a.m. on July 21,1893 , members of the American Library Association (ALA) gathered in the Woman's Building in the White City of the World's Columbian Exposition in Chicago for their seventh conference session of the exposition. As guests of the Board of Lady Managers (BLM), the group responsible for the design, construction, and exhibits of the marvelous building in which they were meeting, they sat in the middle of the rotunda on the building's ground floor. Several members of the BLM mingled with their ALA guests. That the ALA selected Chicago for its 1893 conference was not surprising. During the previous two years the exposition's World's Fair Auxiliary had worked hard to convince hundreds of professional associations to choose the exposition as a site for their annual conferences. In fact, the ALA had committed to the exposition in 1891. Not until June 26, 1893, however, did ALA president Melvil Dewey accept an invitation from Virginia Meredith, chair of the BLM's Committee of Awards, to hold at least one conference session in the Woman's Building. "I will try and make the women specially prominent on that day," he had promised, "and think we can make it be a desirable feature."

What particularly interested the ALA members gathered in the Woman's Building on July 21, 1893, was the library on the building's second floor: a unique collection of printed materials authored, illustrated, edited, or translated by women from all over the world. Never before had

We wish to express our deep gratitude to Faith Barrett, Amy Blair, Kathleen Burt, Michael David Cohen, Jodi Melamed, Angela Sorby, and the anonymous reviewers and the staff of Signs.

${ }^{1}$ Melvil Dewey to Virginia Meredith, June 26, 1893, Dewey Manuscripts, box 3, Melvil Dewey Papers, Rare Books and Manuscripts Reading Room, Butler Library, Columbia University, New York (hereafter Dewey MSS).

[Signs: Journal of Women in Culture and Society 2010, vol. 35, no. 3]

(C) 2010 by The University of Chicago. All rights reserved. 0097-9740/2010/3503-0010\$10.00 
such a collection been assembled. That morning the ALA met in the rotunda to view and commemorate this landmark library. Echoing the rhetoric of progress that saturated the World's Columbian Exposition, Frances Willard, president of the Woman's Christian Temperance Union (WCTU), identified the library as "an amazing collection of books written by women" that demonstrated a history of women in letters. To Willard, the library revealed this history by showing "what a thin long line it was during many centuries, and how it has rapidly broadened out in a magnificent way since education has opened the door to almost every department of science and art" (Willard 1893, 467). Because the rotunda rose to the full height of the building and was capped with a skylight, many of those attending could glimpse the library's entrance from where they sat.

The library upstairs, like the ALA members assembled in the rotunda, represented important components of the culture of print that had evolved and helped to shape history in the four centuries since Columbus landed in the New World. It was a cultural space that invited the exchange of social capital by millions of visitors to the World's Fair. In fact, the room itself - sixty feet long, forty feet wide, and twenty feet high — had several functions. Organizers intended that it exhibit books authored by women since 1492, that it serve as a comfortable and aesthetically distinctive gathering place for visitors to the Woman's Building, and that through a resident librarian it operate as a source of information about women. In addition, the ALA, from whose membership the librarians were drawn, hoped it would model the role women had embraced in pioneering the new professional field of librarianship. These functions were largely complementary; nevertheless, the convergence of the ALA and the BLM at the midpoint of the fair's six-month run brings into focus competing visions of culture and progress that contended within the public space of the Woman's Building and in the larger theater of the Columbian Exposition. These competing visions are nowhere more evident than in the discourses of inclusion and exclusion that informed the cultural projects of the Woman's Building Library and the ALA.

The women responsible for the library's creation were highly conscious of the unprecedented opportunity the Woman's Building afforded to spotlight women's contribution to fine and applied arts, education, family life, service, and other fields in which women had labored. Conscious that women's work had long been undervalued, they were also highly attuned to the enormous advantages, as well as the potential disadvantages, of the venue. Although the question of whether or not women's work should be integrated into exhibits throughout the exposition had been hotly 
contested, advocates of a special women's exhibit hall had ultimately prevailed. Those who opposed a separate exhibit had argued that displaying women's work in isolation would send the message that women were not equal to men and should be judged by a separate standard. Those who advocated for the separate exhibit had objected that if women's work were incorporated into exhibits throughout the fair, it would be less visible and, most likely, unrecognizable as being produced by women. On a less pragmatic level, this debate reflected differing stances on the question of separate spheres. Some women were highly critical of pursuing a course that would emphasize woman's nature as fundamentally distinct and separate from man's. This view, they felt, helped justify the exclusion of women from full participation in the public sphere. Other women remained deeply committed to the ideology of True Womanhood. In the end the decision to erect a special building to house exhibits by and about women reflected a political compromise. While upholding the distinction between women and men, the exhibits and events in the Woman's Building sought to extend the range of women's domestic activities into the public arena. As this compromise reveals, both the physical space of the Woman's Building and the planning and organizing that went into it served as a battleground on which conflicting ideas about women and womanhood vied.

Like the debate over separate or integrated exhibits, the interior design of the Woman's Building Library reflected both a validation of the feminine values associated with separate-sphere ideology, which assigned women to the privacy of the home and barred them from participation in public life, and a critique of the limits of that ideology. In order to signal the resulting combination of values-femininity, domesticity, and benevolence, but also education, progress, and professionalism-the BLM had paid special attention to the aesthetics of the room. The committee responsible for the library's design carefully devised a decor that recalled the reassuring solidity and exclusiveness of a well-appointed private library. In taking this approach, the committee departed from architectural and decorating imperatives of (mostly male) library leaders, who in the $1890 \mathrm{~s}$ preferred to emphasize bureaucratic efficiency and utilitarian purpose in planning library spaces. But Candace Wheeler, the nationally known New York textile designer, artist, and interior decorator who designed the library, had very particular ideas about libraries that emphasized the connection between these traditionally masculine spaces and the feminine sphere of domesticity.

In her book Principles of Home Decoration Wheeler insisted that a home or private library is "not only to hold books, but to make the family at 
home in a literary atmosphere" (Wheeler 1903, 199). Thus, she concluded, the color scheme "may, and should, be much warmer and stronger than that of a parlour pure and simple" (200). And, Wheeler suggests, the aesthetics of the room should blend harmoniously with its natural surroundings, emphasizing the distinctiveness of its location and environment. Later reflecting on the Woman's Building Library, she recalled her desire to integrate its decor with the panorama of Lake Michigan and its boundless horizon: "After seeing the nobility of the room's proportions, and the one great window which seemed to take in all the blue of the sky and the expanse of water which lay under it," she explained, "I felt that it would be an insult to this dominant color to introduce anything in this sheltered space which would be at war with it" (Wheeler 1918, 345). Wheeler stressed that "both its purpose and place demanded the use of every appropriate means of beauty." "Consequently," she "chose modulations of blue and green for the color treatment" of the room $(345){ }^{2}$

The decorating of the library apparently achieved the desired effectthat of recreating the atmosphere of a lavish home library within the public space of the Woman's Building in a manner that harmonized naturally with its physical setting. Maud Howe Elliott, daughter of Julia Ward Howe and editor of Art \& Handicraft in the Woman's Building, praised the domestic character of the interior design, noting that "from a purely artistic standpoint the library is the most important feature of the building, after the Hall of Honor. . . . The room has a character and individuality that we rarely find save in the house of some esthetic lovers of books . . . there is no single apartment in the whole Fair where [the visitor] will find himself so pleasantly at home" (Elliott 1894, 39). Equally impressed, Art Amateur declared it "among the very best bits of interior decoration in the Fair" and described it in terms that suggest an idealized feminine deportment: "The whole effect of the room is reposeful, quiet and cheerful" (Art Amateur 1893, 10). Lady Manager Ellen M. Henrotin pronounced the library "the most beautiful room in the building" (Henrotin 1893,562$)$. The overwhelmingly positive response attests to the success of Wheeler's committee in using interior design to project the outward appearance and feminine values of the private, domestic sphere onto this very public space.

As intimated by Wheeler's allusion to the "nobility of the room's proportions," the exhibits and the decor self-consciously cultivated a cultural

\footnotetext{
${ }^{2}$ For a valuable analysis of Wheeler's theories of aesthetics, nationalism, and femininity, see Blanchard (1993).
} 
elitism that was both Eurocentric and exclusionary. At either end of the library stood two large standards framed with wings, containing a collection of autographs and documents written by such noble women as Queen Mary, Queen Elizabeth, Mary Stuart, Queen of Scots, Catherine de Medici, George Eliot, and Elizabeth Barrett Browning. Affixed to the ceiling, a large painting by Wheeler's daughter, Dora Wheeler (later Dora Wheeler Keith), depicted allegorical figures framed by large oval medallions: enclosed within a border of Venetian scrollwork, the central oval featured mythical female figures representing realms of intellectual endeavor: science, literature, and imagination. Medallions in the corners, which were connected by paintings of drapery intertwined with lilies and streamers, framed the literary genres of history, romance, poetry, and drama in a similar allegorical guise. So as not to strain their necks, viewers could examine the images by peering into a mirror placed atop a large dark oak table in the center of the room, hand carved by the renowned Sypher \& Company with sixteenth-century designs. Visitors could repose in similarly carved antique oak chairs and sofas upholstered in dark green leather by Associated Artists of New York, a firm Candace Wheeler had founded along with Louis Comfort Tiffany. Paneling of the same dark oak lined the walls above the bookcases, on top of which, at calculated intervals, perched specimens of hammered brass and pottery from Rookwood-one of the first companies in the United States to be owned and operated by a woman. On the walls above the bookcases hung portraits of many of the women whose works appeared in the collection; Wheeler also made sure that "busts of notable women by notable women were decoratively used" (Wheeler 1918, 346). All this contrasted sharply with other libraries recently erected across the country, almost all of which exhibited busts of famous men, whose names and literary quotations were often chiseled into building cornices and whose portraits frequently hung over library fireplaces.

In addition to evoking European stateliness and refinement, the decor of the Woman's Building prominently displayed artwork created by American women. In doing so, the library implicitly placed the contributions of American women in the context of European traditions, set their work alongside those of the most admired European women, and distinguished Americans among all the nationalities represented as meriting heightened attention. While some of the items on display alluded to American racial and cultural diversity, these allusions were mediated or interpreted through Eurocentric perspectives. For example, among the many works of art stood a statue of Henry Wadsworth Longfellow's Hiawatha, by African American and Native American sculptor Edmonia Lewis, that Imogen Howard of New York (the lone African American representative among all the state 
BLM delegations) had obtained for the room. Over the fireplace, a specially commissioned reproduction of a Renaissance-era portrait of Pocahontas, wearing a lace ruff and holding a quill pen, drew the eye to this position of prominence. In one corner of the library a five-foot-high mahogany cabinet with glass sides and glass shelves showcased an early portrait of Harriet Beecher Stowe, copies of forty-two translations of Uncle Tom's Cabin, copies of its two-volume first edition, the latest reprint by Houghton Mifflin, and "a beautiful silver inkstand" that Stowe had received from English supporters the year following the publication of Uncle Tom's Cabin - "ten inches in height, eighteen inches wide, and twentyeight in length," a Connecticut official proudly noted - representing "two slaves freed from their shackles" (Weimann 1981, 363-64). A marble bust of Stowe gazed serenely from a granite pedestal nearby. ${ }^{3}$

"Altogether I was satisfied," Wheeler concluded. "I felt that the women of all America would not be sorry to be women in the face of all that women had done besides living and fulfilling their recognized duties" $(1918,346)$. Most visitors seemed to agree. In late June a fairgoer from Canada reported to her local newspaper: "A whole day devoted to this one room would repay one richly" (Sana 1893, 3). ${ }^{4}$ Willard was effusive: "Had the Board of Lady Managers accomplished nothing else than bringing these books together" in this beautiful room, she exclaimed, "it would have done a great deal" (Willard 1893, 467). Most tellingly of the BLM's success in highlighting American women writers and elevating their status, Lady Manager Rebecca A. Felton observed that the library's "very atmosphere became redolent with the greatness of American women in literature and fine art." ${ }^{5}$

With this atmosphere of artistic greatness rising above the tumult of the World's Fair, the Woman's Building and its library, like other sites in the White City, exemplify what Michel Foucault has termed "heterotopias," or other spaces-real, physical places that function like "countersites . . . in which the real sites, all the other real sites that can be found within the culture, are simultaneously represented, contested, and inverted" (Foucault 2004, 374). With their monumental collections of timeless cultural treasures and innovations contained within temporary structures erected specifically for the fair, many of these sites function as two

\footnotetext{
${ }^{3}$ For an analysis of the Stowe exhibit, see Hochman (2006).

${ }^{4}$ R. A. Felton, report of committee on the assignment of space, n.d., Papers of the Board of Lady Managers, box 8, vol. 23, World's Columbian Exposition, Archives and Manuscripts Department, Chicago Historical Society (hereafter BLM Papers).

${ }^{5}$ Ibid.
} 
distinct forms of heterotopia. On the one hand, they epitomize the museum-like heterotopia that seeks to "enclose in one place" a collection or archive that is "outside of time"; on the other hand, they partake of the festival-like heterotopia that is "linked . . . to time in its most fleeting, transitory, precarious aspect" (Foucault 2004, 377).

As they made their way to their conference session on that midsummer morning in 1893, ALA members had ample opportunity to experience the vibrant, up-to-date, eclectic, and carnivalesque atmosphere of the fairgrounds as well as the more sedate and self-consciously refined museumlike exhibits, such as those in the Woman's Building. Like everyone else visiting the White City that day, they had arrived by one of seven means of transportation designed to move them swiftly and efficiently into, out of, and around the grounds. Some had come by rail, alighting from trains on the thirty-five tracks leading into the Terminal Railway Station just behind the Administration Building. Others had taken steamers and disembarked from Lake Michigan. Still others had ridden in horse-drawn coaches from downtown. Some had walked the Midway Plaisance-the mile-long stretch linking Washington Park to the fair. Those who had strolled along the midway had had the opportunity to view a variety of popularized anthropological exhibits. They might have gazed upon provocatively draped women who performed exotic dances. It was here, for example, that the dancer known as Little Egypt introduced America to the belly dance-subsequently called the hootchy-kootchy-which one member of the BLM pronounced "highly immoral and degrading" (Chicago Herald 1893b, 5). Pedestrians of the midway would also have encountered novel entertainments such as the mammoth 265 -foot-high Ferris wheel, which cost five cents per ride and could accommodate 1,440 people at a time.

Inside the park, ALA members could hop aboard an electric railway that circled the exposition grounds every forty-five minutes. Elsewhere launches, small boats, and a fleet of twenty gondolas traversed the waterways, which were regularly patrolled by the U.S. Navy. The ALA members could also enjoy the exposition's clean streets, good-quality drinking water, and 3,116 public toilets: a contrast to what they found throughout most of Chicago. Altogether, the White City was a countersite that corrected what its developers perceived as the flaws of the modern city: it represented, as Alan Trachtenberg has observed, "a truer vision of the real" (Trachtenberg 1982, 231). The White City was clean, pretty, orderly, and homogeneous: an idealized "City Beautiful" codified, categorized, and neatly compartmentalized by geographical space (the Illinois Building, the East India Building, etc.) and socioeconomic sector (e.g., mines, man- 
ufacturing, agriculture, and so forth). ${ }^{6}$ With its rigid allotments of public space and a bureaucratic impulse toward social taxonomies and economic and cultural divisions, the White City was, like all heterotopias, apparently open and accessible to all, yet "hid[ing] curious exclusions" (Foucault 2004, 378).

The Columbian Exposition vibrated with a diversity of world cultures never before assembled in one place. On its 686 acres, 47 different countries and most of the U.S. states and territories displayed some 65,000 exhibits in buildings erected specially for the fair. For all its apparent progressiveness and cosmopolitanism, however, the Columbian Exposition was relentlessly exclusive even as it conveyed the image of openness and inclusiveness. In many of the exhibits, visitors would have found little that documented the contributions of women, the working classes, and other marginalized groups. Prejudice against these groups was often most conspicuous in their absence. Buildings representing Deep South states, for example, exhibited displays that celebrated white cultures and sectional heritage but paid little attention to the cultural contributions and heritage of the millions of African Americans living in their midst (Chicago Herald 1893a, 9; Reed 2000, xxv). Although the Woman's Building Library included some works by African American women (see Gautier 2006), as well as numerous works by white women that addressed racial injustice (Uncle Tom's Cabin, Lydia Maria Child's An Appeal for the Indians, and Helen Hunt Jackson's Century of Dishonor, to name just a few), the BLM had refused to cooperate with African American women who requested representation in the Woman's Building. If members of the ALA noticed such omissions, however, they made no public protest. Like the BLM, the ALA manifested exclusionary cultural biases in the professional practices and services it had advocated since its formation in 1876.

The Court of Honor-both its name and its architecture trumpeting the kind of enduring institutions, timeless values, and elite European lineage celebrated by the White City—constituted the fair's main focal point. At the center of this resplendent enclave sparkled the Great Basin, with Daniel Chester French's sixty-five-foot-high Statue of the Republic towering above the water at the east end and Frederick William MacMonnies's Columbia Fountain splashing and frothing at the west end. Around its banks clustered many of the fair's most magnificent edifices, including the Administration, Electricity, Machinery, Agriculture, Manufactures, and

\footnotetext{
${ }^{6}$ Although the City Beautiful movement, characterized by municipal art, civic improvement, and outdoor art, did not gain its name until 1898 , it was inspired in part by the White City. See Peterson (1976).
} 
Liberal Arts Buildings: a monumental mingling of the marvelous and the mundane. Every day tens of thousands packed into the buildings, walkways, and open spaces of the Court of Honor; every night many thousands remained to witness it shimmering like a fantastic mirage under a flood of artificial light. "Nothing that I have ever seen in Paris, in London, in St. Petersburg, or in Rome," wrote English journalist William T. Stead, "could equal the effect produced by the illumination of the great white palaces" at night (Stead 1894, 415). Stead, like many others who described their experiences of the White City, gives the impression of having stepped into an "unreal, virtual space" (Foucault 2004, 374), a fantasyland of realistic illusion and illusive reality that contradicted and destabilized the image of permanence and timelessness projected by exhibits like the Woman's Building Library.

Fronting the midway, on the northwest quadrant of the exposition grounds, flanked by the Illinois and Children's Buildings, stood the Woman's Building: its physical placement appropriately signposting the social placement of women as embedded in the local, familial, and domestic. ${ }^{7}$ The fair's Department of Horticulture had given permission to Jules Lemoine, principal gardener of the city of Paris, to use the space around the Woman's Building for a floricultural exhibit; as a result of his efforts, meticulously manicured landscaping circled the building, inviting fairgoers to rest on public benches amid "luxuriant shrubs and beds of fragrant flowers" (Truman 1893, 304). Directly in front of the building lay an ornamental lagoon, crowned with a picturesque wooded island. ALA members traversing its waters by gondola could disembark on a convenient landing and walk up to a flower-bedecked terrace six feet above the water's edge and one hundred feet in front of a triple-arched main entrance. Over the entrance, directly beneath a pediment decorated with nineteen-year-old Alice Rideout's bas-relief representations of literature, home life, art, and beneficence (all considered appropriate endeavors within women's sphere), an open balcony afforded a superb view of the lagoon and the attractions beyond its banks. Higher up, above the second floor, perched the Roof Garden Café, capable of serving more than four thousand customers daily. There, visitors of diverse races and nationalities sipped tea and munched quail on toast-a favorite combination and café specialty - the self-consciously feminine refinement of the venue and menu slightly marred by signs on the railings admonishing guests not to spit over the sides.

With dimensions of $199 \times 388$ feet, a footprint of 1.8 acres, and

\footnotetext{
${ }^{7}$ We are indebted to Michael D. Cohen for this insight.
} 
combined floor space of 3.3 acres, the Woman's Building was one of the smallest of the fair's major exhibit halls; nevertheless, it soon became a must-see attraction for visitors to the fair. As Kate Field described it: "If popularity be a sign of approval, the Woman's Building outranks all others. I never entered its portals without being oppressed by an overflow of humanity. Every woman who visited the Fair made it the center of her orbit. Here was a structure designed by a woman, filled with the work of women. Thousands discovered women were not only doing something, but had been working seriously for many generations" (Field 1893, 39). Contemporary observers perceived the Woman's Building as the architectural epitome of feminine dignity and grace. Bertha Palmer, president of the BLM, confidently dubbed it "The American Woman's Declaration of Independence" (Badger 1979, 121) —a rhetorical fusing of national and feminine identities in a pointed inversion of the patriarchal declaration of the country's founding fathers. ${ }^{8}$ Virginia Meredith found the Woman's Building "chaste and delicate," "a restful and refreshing point for the eye" as one gazed along the Court of Honor (Meredith 1893, 418). A number of others echoed Palmer and Meredith in portraying the building in terms of femininity, American identity, or both. To Wheeler, it was "the most peaceably human of all the buildings . . . like a man's ideal of womandelicate, dignified, pure, and fair to look upon" (Wheeler 1893, 836). Elliott described it as "essentially feminine in character," noting that "it has the qualities of reserve, delicacy, and refinement" (Elliott 1894, 25). In pronouncing "the Woman's Building and its deep significance" the "'new birth of our new soil,' the best that is American," C. C. Buel seems to have idealized femininity as the pinnacle of American identity, although, oddly, he also found the Woman's Building "gentlemanly" (Buel 1893, 616-17). Less impressed with the building's design (though no less reliant on stock stereotypes of feminine identity), a male architect quibbled, "Its fault is one which makes it especially suitable for the purpose for which it is to be used-it is chaste and timid" (quoted in Ralph 1893, 162-63). Despite (or perhaps in response to) the widespread use of such stereotypes, the spirit of female solidarity encapsulated in the building's motto-Juncti valemus (United we prevail)—seemed to permeate the atmosphere.

\footnotetext{
${ }^{8}$ Palmer may have been alluding to the much less positive experience at the Woman's Pavilion of the 1876 Centennial Exhibition held in Philadelphia. Denied an opportunity to read their "Declaration of Rights for Women" at the centennial's July 4 festivities, Susan B. Anthony, Phoebe Cousins, and other members of the National Woman Suffrage Association protested by marching into Independence Hall, handing a copy of their declaration to the master of ceremonies, and then marching out to Independence Square to read it to assembled members of the public (Weimann 1981, 4).
} 
To enter the building, visitors walked through one of four entrances leading to the Eastern and Western Vestibules and the North and South Pavilions. These areas housed large exhibition spaces surrounding the 70 $\times 65$ foot rotunda where ALA members convened on the morning of July 21. ${ }^{9}$ Librarians facing the north wall viewed a mural by Mary MacMonnies titled The Primitive Woman. With BLM president Palmer's name emblazoned below, it depicted a male hunter returning from a kill to a group of children and women who carried water, tended babies, and planted crops. Those facing the south wall could contemplate a complementary mural by Mary Cassatt titled The Modern Woman, with building architect Sophia G. Hayden's name inscribed underneath it. In counterpoint to the patriarchal needs-based scene depicted in The Primitive Woman, Cassatt's mural idealized femininity in terms of culture, leisure, and recognition, portraying women and girls playing and listening to music, gathering apples, and pursuing Fame (Burg 1976, 164-65). Poised between the primitive and the modern, guests had abundant opportunity to reflect on the symbolic implications of both their physical and their temporal placement at a fair equally invested in glorifying the past and heralding an even more glorious future.

Inside each entrance visitors could browse at a booth containing articles for sale: a faint yet irrepressible echo of the bustling profit-driven bazaars along the Midway Plaisance. Here they might purchase miniature models of the Woman's Building itself, the official flag of the Columbian Exposition, souvenir spoons, and commemorative coins. They could buy guide books, collections of recipes compiled by the lady managers especially for the World's Fair, and other fairground publications, including The Story of the Woman's Building, adapted from Three Girls in a Flat, a novel Laura Hayes (Palmer's private secretary) coauthored with Enid Yandell (who sculpted the caryatids on the Woman's Building) and Jean Loughborough (Palmer's record keeper and file clerk). Also for sale were copies of the Distaff Series, a six-volume collection of "tastefully represented" anthologized periodical articles written by New York women, put together by the state's lady managers and marketed by Harper Brothers (Harper's Bazaar 1893, 398). The first-floor rooms on the east side of the rotunda housed exhibits of women's inventions, education, and progress. Rooms on the west side accommodated a souvenir shop, a scientific exhibit, and facilities for checking coats and handbags, mailing letters, and

\footnotetext{
9 The information describing the interior of the Woman's Building is taken from an undated report of the Board of Lady Managers, BLM Papers, vol. 8. See also Garland (1893, 284). For a description of the pavilions, see Moses P. Handy (1893, 178-79).
} 
making telephone calls. Stairways located at the four corners of the rotunda led up to a second floor, where cloisterlike galleries overlooking the rotunda opened through arches to a series of interior rooms.

Although one fourth of the exhibit space in the Woman's Building featured American work, most of the first floor was devoted to the fortyone foreign exhibitors, including works that came from "savage and halfcivilized nations, such as Siam, Ceylon, and even Africa" (Wade 1893, 159). In many cases, exhibits of non-Western materials were prepared and presented by American women who had put them on display as exotic and inferior "others." Here, for example, ALA members could peruse an exhibit titled Woman's Work in Savagery, courtesy of the Smithsonian Institution (Woods 1893, 253; Weimann 1981, 393-404; see also Gullet 1994, 270). These exhibits offered the semblance of an inclusiveness that was persistently undercut by the cultural chauvinism through which it presented non-European cultures. ${ }^{10}$

Above the South Pavilion-just off the galleries-librarians found the administrative headquarters for the BLM as well as the Organization Room, which housed displays by the Daughters of the American Revolution, the WCTU, and the Association of Collegiate Alumnae. ${ }^{11}$ A public exhibit of materials generated by nearly half of the 278 member clubs in the recently founded General Federation of Women's Clubs formed an additional attraction. "Within it," noted WCTU president Willard, "lies the impressive representation of the noblest work of women" (Willard 1893, 464). The display of club yearbooks, lists and portraits of officers, and printed study guides made possible the kinds of "textual exchanges" that, as Anne Ruggles Gere argues, had for years "strengthened bonds among women separated by distance and/or time, adding an affective dimension to their literacy practices" (Gere 1997, 8). Here, "many clubwomen from various parts of the country spent long hours, even days, studying the materials, making penciled notes, and discussing club methods with each other" (Gullett 1994, 267). Absent from the room, however, was any reference to clubs such as the Knights of Labor or the American Federation of Labor. As early as April 17, 1892, Charlotte Smith, president of the Woman's National Industrial League of America, had complained to an audience of Waverly Hall Socialists in Chicago that "working women are not represented in the $[\mathrm{BLM}]$ board; neither were

\footnotetext{
${ }^{10}$ For an insightful overview and analysis of the linked ideologies of imperialism and New Womanhood at the World's Columbian Exposition, see Boisseau (2000).

${ }^{11}$ Several decades later, the Association of College Alumnae merged with the Southern Association of Collegiate Women to become the American Association of University Women.
} 
red women and black women" (Daily Inter Ocean 1892, 4). These exclusions illustrate that the exhibits in the Woman's Building Library were, to a large extent, constructions that the BLM and affiliated women had fashioned in their own image.

In rooms above the North Pavilion fairgoers found the Tea Room, the Model Kitchen, and the Assembly Room, which was largely used for lectures. On the east side of the rotunda, just off the galleries, lay an office for the building's superintendent, the Public Comfort Room, the Japanese Room, and the Kentucky, Cincinnati, and California Parlors. The west side contained the North Carolina Room, the Connecticut Room, the British Nursing Exhibit, a miscellaneous exhibit room, and, separated from the adjacent records rooms by heavy blue draperies, the library-"the most elaborate apartment in the building," according to Meredith (1893, $418) .{ }^{12}$

Before ascending to the library itself, the members of the ALA who gathered in the rotunda on the morning of July 21 listened to a series of papers on the subject of librarianship. Ellen M. Coe of the New York Free Circulating Library read a paper titled "Fiction." The "Membership of A.L.A.," she concluded, "gives forth no uncertain sound as to the necessity and duty of restricting the provision of Fiction (novels, strictly so speaking) to the smallest possible quantity of the best quality" (Coe 1893, 236). Although Coe did not comment on the fact, her observation points to a significant contrast between the ALA's practices and the content of the Woman's Building Library. In fact, in the Woman's Building Library, where gender identity and the desire to present a visually impressive quantity of materials trumped concerns over quality, the largest category of books by far consisted of volumes of fiction. ${ }^{13}$

Other papers addressed such topics as "Reading of the Young," "Reference Books," "The Executive Department: General Supervision," and "Pamphlets." All the subjects represented conventional topics in professional library discourse; none spoke to the gendered distinctions that the Woman's Building self-consciously profiled and the library exuberantly celebrated. Not until Dewey, ALA president and New York State librarian, introduced Mary Trautmann, first vice president of the BLM, did the ALA officially acknowledge its surroundings (Library Journal 1893, 250-57) ${ }^{14}$

"Every member of the board is proud of [the library]," Trautmann

\footnotetext{
${ }^{12}$ For other descriptions of the library, see Banks $(1893,641)$ and Willard $(1893,460$, 464).

${ }^{13}$ For more about texts in the Woman's Building Library, see Wadsworth (2006).

${ }^{14}$ For transcripts of the papers, see Library Journal (1893, 236-38, 250-57).
} 
announced, "and I am particularly so, being a New York woman." She then acknowledged the preeminent role New York women had played in decorating the library and gathering books for its collections. Dewey thanked her for her remarks with a flurry of compliments. "I came out here on official business before the fair opened," he said, "and found the woman's building by far the most advanced. After the opening I came in here and found all moving as smoothly as if these women, and not their brothers, had received the business training of centuries." He reported that more than twenty people had told him that the Roof Garden Café was the "best managed" on the entire fairgrounds. "I am sure," he affirmed, "that the men of the A.L.A., which has always given to woman full recognition as co-workers, will share my pride in the splendid showing she has made at the world's greatest exposition" (Library Journal 1893, 67). His comments tactfully concealed an attitude he expressed elsewhere, that the Woman's Building Library emphasized art at the expense of professional efficiency. ${ }^{15}$

As he finished his remarks, Palmer entered the rotunda. Librarians present already had had ample opportunity to recognize her. Against a background of the Woman's Building, her likeness had been woven into silk bookmarks, printed on playing cards and postcards, and minted into souvenir spoons, all of which were available for sale throughout the fairgrounds. At one time, she was told that "except the Ferris Wheel" she was the fair's most popular attraction (quoted in Burg 1976, 247). Taking care to emphasize that an appropriate public role need not compromise a woman's domestic competence, Dewey introduced her as a "lady who is as graceful and gracious and efficient at the head of this great administrative work as at the head of one of the most beautiful, hospitable, and palatial homes for which this wonderful city is becoming famous" (Library Journal 1893, 68). His emphasis on Palmer's dual roles in the public and private spheres clearly resists the assumption that women's domestic prowess depends upon their separation from the public sphere, just as his choice of the word "head" repudiates the oft-cited dictum that the role of head of the household belongs to men while women's role is to be its heart.

Palmer, a native Kentuckian "whose Southern vowels flowed like wine and carr[ied] her audience with them where she will[ed]" (Mrs. M. P. Handy 1893, 610), cordially congratulated the ALA for its work for the nation and praised Dewey, "who has been our good adviser and friend throughout" (Library Journal 1893, 68). "Through his kindly influence and mediation," she explained, "we have been able to show in this building

${ }^{15}$ See, e.g., Dewey to Edith Clarke, April 21, 1893, Dewey MSS, box 3. 
the work of expert librarians in this country, and we feel very much gratified that in this work women bear so distinguished a part." Librarianship, she believed, was one of the "new avocations that are being fitted to the intelligence, refinement, systems, and order, and many other qualities that are shown pre-eminently by women" $(68)$. She also noted that the collections and services evident in the library represented one of the best examples of this new vocation. To the assembled librarians she said she hoped that the ALA's influence "may spread and radiate . . . all over the world." Her comments, which obviously harmonized with prevailing views of the distinct and elevated nature of womankind as well as with the ALA's educational mission and the exposition's ethos of cultural imperialism and globalizing progress, met with enthusiastic applause (Library Journal 1893, 68).

Not coincidentally, the same day the ALA met in the rotunda, Mary Lockwood, chair of the committee in charge of the Woman's Building Library, had issued a summary report to the BLM's Executive Committee. She noted that as of July 21 the library contained over seven thousand volumes in sixteen languages from twenty-three countries and every U.S. state and territory but nine, with more books arriving daily. She reported that 1,453 women elsewhere in the world had identified and selected the 3,467 foreign books, while 2,628 American women representing 31 out of 40 states and territories had participated in the identification and selection of 4,780 books by American female authors. As she enumerated state contributions, it was evident that the BLM had revised the late nineteenth century definition of library, expanding it to include - and even generatecultural texts that most libraries of the day chose not to collect. ${ }^{16}$

To identify what was in the collection, Lockwood reported, visitors had access to a partially completed, alphabetically arranged subject-author public catalog of nearly nine thousand cards. This card catalog contained two types of entries. One gave statistics of each author represented in the collection and included date and place of birth and death (if applicable), along with information about the author's education and life work. The other gave conventional library information on each book in the collection and contained a Dewey Decimal Classification (DDC) number representing a classification scheme that Dewey himself had developed as an Amherst College librarian between 1874 and 1876 and that, in 1893, was being adopted by the increasing number of public libraries opening up

${ }^{16}$ The BLM's international appeal for writing by women resulted in a host of books conceived especially for the occasion: scrapbooks, club histories, cookbooks, literary miscellanies, and even novels, many of them edited or authored by affiliates of the lady managers. 
in communities across the nation. In this instance, the BLM had made a deliberate decision to follow the lead of the nation's developing library profession. "The peculiar excellence of a card catalog," Lockwood instructed, was "that new books can always be inserted without interference and it can be arranged and rearranged in any manner desired." Lockwood also explained that librarians in the Woman's Building Library were informing visitors that at the conclusion of the exposition the BLM intended to publish a printed catalog of the library's collection, all arranged in a single DDC scheme. ${ }^{17}$

The Woman's Building Library was an astonishing collection, representing pioneering work of which the BLM was justifiably proud. Yet ALA visitors perusing the stacks after the meeting in the rotunda had adjourned could not help but notice three unusual features that distinguished the library from modernizing American public libraries. First, visitors were not permitted to pull books from the shelves and page through their contents. As ALA members recognized, closed stacks marked a dated philosophy of service that venerated the book as an artifact, a treasure to be protected. On the other hand, open stacks, which increasingly characterized modern-day library practice, celebrated the book as a useful tool in self-education. The decision in favor of closed stacks enhanced the timeless, museum-like quality cultivated by the organizers of the Woman's Building Library at the expense of usability and service.

Second, the books themselves were arranged first by the state and/or country of authors represented and then, depending on the size of the state or country's contribution, by subject. This geographical organizational scheme, running counter to a basic premise of library service manifest in the uniform subject-author public catalog, reflected political divisions within the BLM even as it reinforced the primacy of nationalism and regionalism as cultural forces in late nineteenth-century America. To Dewey and the disciples of his classification system (almost all of whom were female), however, this arrangement constituted professional heresy.

Third, the contents of the library frequently tested contemporary definitions of quality. Library professionals of the late nineteenth century were adamant about their responsibility to elevate the taste of the reading public they served with quality books endorsed and legitimated by cultural authorities. They operated on the assumption that if their libraries made

\footnotetext{
${ }^{17}$ Mary Lockwood, Report of the Woman's Library, July 21, 1893, BLM Papers, vol. 23, box 8; Amy Starkweather, "Assignment of Space in Woman's Building," n.d., in the "Classification" section, BLM Papers, vol. 30, box 10.
} 
only good books available to readers, they would make a substantial contribution to solving problems attending immigration, industrialization, and urbanization by enabling the masses to educate themselves, thereby reducing threats to the social order. This commitment was most evident in the Model Library of five thousand titles the ALA had put together for its exhibit elsewhere on the grounds. A year later the U.S. Bureau of Education published a bibliography of this Model Library, Catalog of A.L.A. Library, and distributed free copies to any public library requesting one. Thereafter it became a staple collection guide in the public library movement, which was accelerated by Andrew Carnegie's philanthropy. But, as casual observers might discover, the Woman's Building Library did not reflect the same commitment to quality literature. In addition to a host of cookbooks, the collection included many self-published texts issued in small editions, along with various kinds of ephemera, privately circulated volumes such as scrapbooks and manuscript books, and novels by popular authors excluded from the ALA Catalog: E.D.E.N. Southworth, Laura Jean Libbey, and many others. ${ }^{18}$ Also included were devotional books and Sunday school texts. As Coe's address on "Fiction" had emphasized, the Model Library restricted the number of novels to "the smallest possible quantity of the best quality" (Coe 1893, 236); based on statistics gathered from a sampling of American public libraries, the ALA had devoted only 15 percent of the Model Library to works of fiction. In contrast, fiction comprised nearly double that percentage of texts in the American section of the Woman's Building Library.

The tension manifested between the desire to create a truly comprehensive collection of women's writing and the desire to showcase only the best reflects an inherent contradiction between the inclusive and the restrictive that the BLM neither resolved nor fully addressed. Long before the ALA's visit to the Woman's Building, this conflict had reverberated through discussions held during the planning stages of the library. Palmer aspired to create "a systematic thoroughly classified and well-filled library of books written by women upon all lines of thought" (Weimann 1981, 359). At the same time, the BLM wished "to keep this [the Woman's] exhibit very choice" (Weimann 1981, 280), formalizing this objective in the official rules for the library: "In the Library, only books of scientific, historical, and literary value will be received." 19 Yet the question of how

${ }^{18}$ For a discussion of the religious texts in the Woman's Library, see Brown (2006).

19 See resolutions adopted by the BLM Executive Committee, October 31, 1892, BLM Papers, vol. 8. 
to assess literary value remained unresolved, and probably deliberately. There seems to have been a tacit assumption that a consensus would eventually prevail over what was choice and what was second rate.

In practice, however, the competing ideals of comprehensiveness and selectiveness gave way to a host of other considerations, both logistical and ideological, as the ideal of the museum clashed with the reality of the fairground. To begin with, the task of gathering all the productions of the feminine pen from centuries gone by to the present day was commendable but ultimately unachievable. Writing by women had not been recorded, tracked, and preserved as such in a systematic way. Moreover, the possibilities of recovering very old, rare, and obscure texts, regardless of quality, were few. And, given the racial politics at work within the BLM and in the Columbian Exposition more broadly, the idea that the Woman's Building Library was representative of all women-or even all women writers - must be modified to acknowledge its white, middle-class bias.

The conflicting currents of the Woman's Building Library converged uneasily to produce a unique and contradictory blend of the timeless and the time bound. In pragmatic terms, the result was a peerless collection of predominantly nineteenth-century books shaped by a sociohistorical reality that the library both reflects (through inclusion) and refutes (through exclusion). Summing up her understanding of the library shortly after the fair's grand opening, head librarian Edith Clarke emphasized: "The library . . . is an exhibit, rather than a working library. It is intended to be complete, not competitive, and its scope includes all books written by women, especially since $1800 .{ }^{20}$ Clarke also noted that the books were collected by states and countries, and because these separate collections emanated from different committees they manifested "a want of evenness and uniformity." Some states and countries had sent all books by all authors, some "only their best," some only one book from each author, and some books by living authors only. ${ }^{21}$

In addition to revising contemporary definitions of literature, the Woman's Building Library also significantly revised accepted conceptions of library space. Although Carnegie's turn-of-the-century philanthropy stimulated a movement that soon made the American public library a ubiquitous civic institution, in the vast majority of communities much of the impetus for starting these libraries came originally from women's organizations. The thousands of women's club members who visited the

\footnotetext{
${ }^{20}$ Edith Clarke, "The Library in the Woman's Building," 1893, BLM Press Committee, Dewey MSS, box 3 .

${ }^{21}$ Ibid.
} 
Woman's Building Library in Chicago and subsequently returned to their communities to help establish the public libraries Carnegie money had made possible had particular ideas about how those libraries should look, inside and out. In almost every case a small-town public library built after 1893 was located on Main Street. In almost every case it boasted a wellmanicured lawn with inviting landscaping on the outside and on the inside housed comfortable furniture and attractive accessories and decorations. Rare was the public library, in fact, that did not frequently sport fresh floral arrangements donated and regularly changed by local women's organizations. All this was done to make users feel "at home in a literary atmosphere" (Wheeler 1903, 199). In this endeavor, women's organizations did not take their cues from the library profession (which privileged bureaucratic efficiency over aesthetics), and although they may not have directly followed the lead of the Woman's Building Library, its existence helped to legitimate what they did to public libraries in their own home towns.

Perhaps ironically, the Woman's Building maintained its symbolic power in part through the BLM's determination that it should function chiefly as a display or spectacle rather than a working library: yet another mindblowing array of objects in the vast exhibit hall of the Columbian Exposition. Those who described it firsthand frequently reported being overwhelmed by the sight that greeted them. They were struck by the palatial repository with its elaborate decor. They admired the exquisite gilding, ornate moldings, richly adorned Renaissance-style fireplace, neoclassical frieze, Turkish carpets, stained-glass windows, and intricately carved tables and chairs. Most of all, however, they stood in awe before the walls upon walls of gleaming oak bookcases packed with seemingly countless volumes of books and periodicals: an imposing, monolithic monument to the literary genius of women. As Wheeler marveled: "The bookcases themselves surrounded the room, filled with books, a great army of them beginning with the very earliest utterances of women in print and following down the centuries to the present" (Wheeler 1918, 346). Wheeler refrained from remarking on the texts themselves beyond the impression they made in the aggregate as a spectacular exhibit of women's literary productivity. Evidently, the power of the scene lay in the immensity and grandeur of the room itself and in the cumulative effect of viewing seven thousand volumes of women's writings at once. Highlighting a handful of authors represented in this mammoth collection-Harriet Martineau, George Eliot, Frances Burney, Lady Jane Grey, Jane Austen, and Charlotte BrontëMinneapolis journalist Marian Shaw echoed Wheeler's imperialistic metaphor ("a great army" of books) when she pronounced, with similarly 
aggressive and self-consciously masculine rhetoric, that "the library . . . gives indisputable evidence of woman's inherent right to occupy the field of literature, since . . . in this department she has 'come, seen and conquered" (Shaw 1992, 63).

Caroline Garland, the public library director for Dover, New Hampshire, cautioned that "a captious critic" might argue that many practices in the Woman's Building Library are "not in accordance with advanced library ideals." Nevertheless, Garland pointed out, "it must be remembered that this is not a working library, but an exhibit, and as such should be arranged as artistically as possible" (Garland 1893, 284). Other librarians at the July 21 meeting were not so gracious and privately pointed to the ALA library as a much better model. ${ }^{22}$ However, no one mentioned the contrast in the official remarks recorded that day in the rotunda. Katharine L. Sharp, director of the Armour Institute Library in Chicago and a Dewey protégée, made no adverse comparisons in her published description of the ALA Model Library (Sharp 1893), and no ALA member publicly criticized the arrangement of materials in the Woman's Building Library. Although the ALA's commitment to professionalizing librarianship conflicted in several ways with the BLM's commitment to gender, none of these conflicts became public. The Woman's Building Library obviously represented a labor of love that was politically negotiated through the many groups of women who had a shared interest in putting it all together.

The Woman's Building Library constituted a record of a public sphere, manifesting an increased democracy for some women but at the same time silently imposing boundaries on that public sphere outside of which some continued to reside. Clubwomen had invested so much in an ideology of literacy that promised to improve life for women materially and emotionally, and the Woman's Building Library afforded a foundational footing for that ideology. It demonstrated historically the "textual alliances" (Gere 1997, 100) that clubwomen in the 1890s experienced personally. Compared to the ALA Model Library, in many ways the Woman's Building Library reflected a much broader view of culture, which contested the genteel traditions and canonical texts the dominant patriarchy promoted, albeit in quiet, nonthreatening ways. Perhaps the willingness to let gender expand the definition of culture chilled the atmosphere for professional librarians, many of whom were committed first to their profession, which for a quarter century after the organization of the ALA argued for a more elevated definition of culture: "the best reading for the greatest number

${ }^{22}$ Melvil Dewey to Edith Clarke, April 21, 1893, Dewey MSS, box 3. 
at the least cost" was the ALA motto. While the ALA library reflected that motto, the Woman's Building Library, reflecting its own motto of female unity, Juncti valemus, allowed gender to take precedence over the "best reading." Some librarians had difficulty with this; rather than join in the celebration of the Woman's Building Library, they chose to remain silent.

Unfortunately, both the temporary nature of the Columbian Exposition and the collaborative development of the literary exhibit worked against its preservation as an intact entity. The White City was eventually destroyed, the venerable BLM was ultimately disbanded, and plans to retain the library in its own permanent collection never materialized. It was nearly inevitable, therefore, that the Woman's Building Library would be broken up, scattered, and, in part, lost or destroyed: the temporality of the fair's festival-like ethos winning out over the timelessness of the museum. In addition, the compressed time frame of the Columbian Exposition made it impossible for the professional library staff that Dewey had handpicked for the BLM to complete the gargantuan task of cataloging for posterity the collection in the professional manner they had hoped to do. Moreover, budget constraints prevented the creation of an unabridged printed catalog from the card catalog that had been prepared on-site. ${ }^{23}$ These budget priorities demonstrate that the BLM considered the catalog less important than the physical collection itself and the manner in which it was exhibited. Ironically, the board's inability and/or unwillingness to conform to the discursive formations of the emerging profession of librarianship may also have substantially undermined their efforts to pass down to future generations an enduring record of women's writing.

The conflicting agendas of the BLM and the ALA are evident in the responses of the ALA to the library in the Woman's Building as well as in the competing discourses of professionalism and gender identity that informed their projects. The ALA promoted professionalism but, in doing so, advocated a narrowly construed definition of culture. The BLM emphasized the solidarity of women ("women clasping hands with women," as one lady manager put it) but, in doing so, advocated a narrowly defined construction of feminine identity. ${ }^{24}$ While the ALA Model Library mirrored the former, the Woman's Building Library reflected the latter.

${ }^{23}$ Head librarian Clarke and her assistants did manage to complete the shelf list and the card catalog (consisting of nine thousand cards containing biographical and bibliographic data). While their List of Books (Clarke 1893) survives, the more ambitious card catalog has not been recovered.

${ }^{24}$ The phrase is taken from a speech given by a lady manager, Mary Logan, Logan Manuscript Division, box 50, Library of Congress, Washington, DC. 
Although advertised as a unified collection of women's writing from all places and all times, the Woman's Building Library actually comprised scores of discrete collections sent in by state and national committees with widely varied responses to the question of inclusiveness. On the one hand, the inclusiveness of the collection in terms of genre, literariness, and subject matter illustrates the breadth, depth, and diversity of women's contribution to print culture (particularly in the United States) up to 1893. On the other hand, the exclusiveness of the collection in terms of the class and ethnicity of the women who contributed to it illuminates the mechanisms involved in the mediation and erasure of race and class in women's print culture. Not coincidentally, both the canon building of the ALA and the self-conscious gender construction and negotiation of the BLM crystallized in the historical era that gave rise to the professionalization of librarianship as well as the formulation of literary history as an expression of national identity and gender politics.

School of Library and Information Studies

Florida State University (Wiegand)

Department of English

Marquette University (Wadsworth)

\section{References}

Art Amateur. 1893. "Women's Work in the Fine Arts." Art Amateur 29(1):10.

Badger, Reid. 1979. The Great American Fair: The World's Columbian Exposition and American Culture. Chicago: Hall.

Banks, Nancy Huston. 1893. "Woman's Marvellous Achievements." In The World's Fair as Seen in One Hundred Days, ed. H. D. Northrop, 632-50. Philadelphia: Ariel.

Blanchard, Mary W. 1993. "Anglo-American Aesthetes and Native Indian Corn: Candace Wheeler and the Revision of American Nationalism." Journal of American Studies 27(3):377-97.

Boisseau, T. J. 2000. "White Queens at the Chicago World's Fair, 1893: New Womanhood in the Service of Class, Race, and Nation." Gender and History 12(1):33-81.

Brown, Candy Gunther. 2006. "Publicizing Domestic Piety: The Cultural Work of Religious Texts in the Woman's Building Library." Libraries and Culture $41(1): 35-54$.

Buel, C. C. 1893. "Preliminary Glimpses of the Fair." Century Illustrated Magazine 45 (February): 615-25.

Burg, David F. 1976. Chicago's White City of 1893. Lexington: University Press of Kentucky. 
Chicago Herald. 1893a. "Days for Southrons." Chicago Herald, August 5, 9. . 1893b. "World's Fair Yesterday." Chicago Herald, August 4, 5.

Clarke, Edith. 1893. List of Books Sent by Home and Foreign Committees to the Library of the Woman's Building. Chicago: Board of Lady Managers. http:// digital.library.upenn.edu/women/clarke/library/library.html.

Coe, Ellen M. 1893. "Fiction." Library Journal 18(8):236-38.

Daily Inter Ocean. 1892. "Still Talks Wildly: Charlotte Smith Harangues the Waverly Hall Crowd.” Daily Inter Ocean, April 18, 4.

Elliott, Maud Howe, ed. 1894. Art \& Handicraft in the Woman's Building of the World's Columbian Exposition. Chicago: Rand, McNally.

Field, Kate. 1893. "Woman and the Fair." Chicago Daily Tribune, November 12, 39.

Foucault, Michel. 2004. "Texts/Contexts: Of Other Spaces." In Grasping the World: The Idea of the Museum, ed. Donald Preziosi and Claire Farago, 371-79. Aldershot: Ashgate.

Garland, Caroline Harwood. 1893. "Some of the Libraries at the Exposition." Library Journal 18(8):284-88.

Gautier, Amina. 2006. “African American Women's Writings in the Woman's Building Library." Libraries and Culture 41(1):55-81.

Gere, Anne Ruggles. 1997. Intimate Practices: Literacy and Cultural Work in U.S. Women's Clubs, 1880-1920. Urbana: University of Illinois Press.

Gullett, Gayle. 1994. “'Our Great Opportunity’: Organized Women Advance Women's Work at the World's Columbian Exposition of 1893." Illinois Historical Journal 87 (Winter): 259-76.

Handy, Moses P., ed. 1893. The Official Directory of the World's Columbian Exposition, May 1st to October 30th, 1893: A Reference Book of Exhibitors and Exhibits; of the Officers and Members of the World's Columbia Exposition and the Board of Lady Managers; A Complete History of the Exposition. Chicago: Conkey.

Handy, Mrs. M. P. 1893. “The Women of the World's Fair City.” Munsey's 8(6): 607-13.

Harper's Bazaar. 1893. "Work of the New York Women at the Columbian Exposition.” Harper's Bazaar 26 (May 20): 398.

Henrotin, Ellen M. 1893. “An Outsider's View of the Woman's Exhibit.” Cosmopolitan 15 (September): 560-66.

Hochman, Barbara. 2006. “Uncle Tom's Cabin at the World's Columbian Exposition." Libraries and Culture 41(1):82-108.

Library Journal. 1893. "Proceedings of the Annual American Library Association Conference, 1893." Library Journal 18 (suppl.): 1-335.

Meredith, Virginia C. 1893. "Woman's Part at the World's Fair, I: The Work of the Board of Lady Managers." Review of Reviews 7 (May): 417-19.

Peterson, Jon A. 1976. "The City Beautiful Movement: Forgotten Origins and Lost Meanings." Journal of Urban History 2(4):415-34.

Ralph, Julian. 1893. Harper's Chicago and the World's Fair. New York: Harper. 
Reed, Christopher Robert. 2000. "All the World Is Here!" The Black Presence in the White City. Bloomington: Indiana University Press.

Sana. 1893. "Woman's Triumph: The Ladies' Exhibit at the World's Fair. Manitoba Free Press, June 26, 3.

Sharp, Katharine L. 1893. "The A.L.A. Library Exhibit at the World's Fair." Library Journal 18(8):280-84.

Shaw, Marian. 1992. World's Fair Notes: A Woman Journalist Views Chicago's 1893 Columbian Exposition. St. Paul, MN: Pogo.

Stead, William T. 1894. "My First Visit to America: An Open Letter to My Readers." Review of Reviews 9 (April): 410-17.

Trachtenberg, Alan. 1982. The Incorporation of America: Culture and Society in the Gilded Age. New York: Hill \& Wang.

Truman, Benjamin Cummings. 1893. “The French Floricultural Exhibit.” In History of the World's Fair: Being a Complete Description of the World's Columbian Exposition from Its Inception, 303-5. Chicago: Mammoth.

Wade, Stuart C. 1893. Rand, McNally \& Co.'s Handbook of the World's Columbian Exposition. Chicago: Rand, McNally.

Wadsworth, Sarah, ed. 2006. “The Woman's Building Library, World's Columbian Exposition, 1893." Special issue, Libraries and Culture 41, no. 1.

Weimann, Jeanne Madeline. 1981. The Fair Women: The Story of the Woman's Building, World's Columbian Exposition, Chicago, 1893. Chicago: Academy Chicago.

Wheeler, Candace. 1893. “A Dream City.” Harper's 25 (May): 830-46.

- 1903. Principles of Home Decoration, with Practical Examples. New York: Doubleday, Page.

1918. Yesterdays in a Busy Life. New York: Harper.

Willard, Frances. 1893. “Woman's Department of the World's Fair.” In The World's Fair: Being a Pictorial History of the Columbian Exposition, ed. William E. Cameron, 448-70. Chicago: Columbia History Co.

Woods, Katharine Pearson. 1893. "Books Old and New." Far and Near 4 (October): 253. 